\title{
COMMENTS
}

\section{LUJAN v. DEFENDERS OF WILDLIFE: STANDING AS A JUDICIALLY IMPOSED LIMIT ON LEGISLATIVE POWER}

\author{
RICHARD J. PIERCE, JR. $\dagger$
}

\section{INTRODUCTION}

I find little to quarrel with in Dean Nichol's critique ${ }^{1}$ of Justice Scalia's opinion in Lujan v. Defenders of Wildlife. ${ }^{2}$ I base my criticisms of the opinion on somewhat different grounds. I am sympathetic to one version of what Dean Nichol calls Justice Scalia's "broader agenda"3-reducing the role of the judiciary in making government policy. That agenda antedates Justice Scalia's appointment to the U.S. Supreme Court; it has been ongoing since 1972. ${ }^{4}$ Many of its central elements have garnered support from every Justice who has served during the last two decades. ${ }^{5}$ However, Justice Scalia's opinion in Defenders cannot be characterized accurately as part of that agenda. As Dean Nichol recognizes, it seems to be instead the first step in implementing a quite different agenda-reducing the permissible role of Congress in government policymaking.

This is the most basic of several criticisms I have of the opinion. I make three main points in this Comment. The first is that Justice Scalia's opinion in Defenders is an insupportable judicial

$\dagger$ Paul J. Kellner Professor of Law, Columbia University. B.S. 1965, Lehigh Unjversity; J.D. 1972, University of Virginia. This Comment is based on remarks presented at a symposium on Lujan v. Defenders of Wildlife held at Duke University School of Law on January 21, 1993. I am grateful to Peter Strauss and Henry Monaghan for their helpful comments on an earlier version of this Comment.

1. Gene R. Nichol, Jr., Justice Scalia, Standing, and Public Law Litigation, 42 DUKE L.J. 1141 (1993).

2. 112 S. Ct. 2130 (1992).

3. Nichol, supra note 1 , at 1166 .

4. See infra text accompanying notes 124-38.

5. See cases cited infra notes 125-38. 
contraction of the legislative power to make judicially enforceable policy decisions. ${ }^{6}$ As such, it is readily distinguishable both from prior opinions in which the Court has reduced the scope of review of agency policy decisions and from prior opinions in which the Court has held that plaintiffs lacked standing to obtain judicial review of agency policy decisions. Second, if the Court were to interpret and apply the broad reasoning in Defenders in all cases, the opinion would be the source of widespread harm to the process of agency policymaking, reducing dramatically the range of interests effectively represented in most agency proceedings. ${ }^{7}$ That, in turn, would increase significantly the tendency for agency policies to be distorted by factionalism. Third, the opinions in Defenders are difficult to interpret. ${ }^{8}$ A majority of the Justices held unconstitutional as applied the statutory provision explicitly authorizing judicial review of an agency rule at the behest of Defenders of Wildlife. The nature of the constitutional defect, however, is difficult to identify. Plausible interpretations of the defect include: Plaintiff's choice of an inappropriate affiant; the affiant's failure to purchase a plane ticket; inadequate legislative specification of the purpose of the statute; or the existence of strict constitutional limits on Congress's power to authorize the courts to enforce statutory commands against agencies. The uncertainty is in itself a problem; many of the plausible interpretations are themselves very problematic.

\section{WHAT IS THE HOLDING IN DEFENDERS?}

The Endangered Species Act (the Act) requires federal agencies to consult with the Department of the Interior (the Department) to "insure [sic] that any action authorized, funded, or carried out by such agency . . . is not likely to jeopardize the continued existence of any endangered species or threatened species or result in the destruction or adverse modification of habitat of such species which is determined by the Secretary ... to be critical ...."9 After years of controversy and vacillation on the issue, the Department issued a rule stating that the Act does not apply

\footnotetext{
6. See infra text accompanying notes $139-47$.

7. See infra text accompanying notes 119-23.

8. See infra text accompanying notes 13-103.

9. 16 U.S.C. $\S 1536(a)(2)$ (1988).
} 
to federal agency projects undertaken in foreign nations. The rule thus permitted federal agencies to fund foreign projects without first consulting with the Department to determine whether the projects would have an effect on endangered species, an effect that would have prohibited funding if the projects were undertaken in the United States.

The Endangered Species Act explicitly authorizes "any person" to obtain judicial review of an agency action that allegedly violates the Act. ${ }^{10}$ Under this provision, Defenders of Wildlife sought judicial review of the Department rule. It claimed to have standing deriving from the injuries to two of its members. ${ }^{11}$ Each member submitted an affidavit alleging that: (1) Each had a personal and professional interest in observing a particular endangered species (the Nile crocodile and the Asian leopard, respectively); (2) each had visited the habitat of that species in the past; (3) each planned to visit the habitat to attempt to observe the species in the future; (4) each species' habitat was threatened by specific projects that federal agencies had agreed to fund (in Egypt and Sri Lanka, respectively); and, (5) each affiant was injured by the rule because it would allow federal agencies to fund projects that threatened the habitat of endangered species the affiants wanted to observe in the future to further their personal and professional interests. ${ }^{12}$

A six-Justice majority held that Defenders of Wildlife lacked standing to seek review of the rule. Since the statute explicitly conferred standing on "any person" to obtain judicial review of a Department rule pursuant to the $\mathrm{Act}^{13}$ the majority necessarily held the statute unconstitutional as applied. Because of its multiple opinions, however, the case raises more questions than it resolves. Justices Kennedy and Souter, who joined in other portions of the majority opinion, declined to join that portion dealing with redressability. The two wrote a separate concurrence that differs with the majority opinion in other important respects as well. ${ }^{14}$

10. Id. \& $1540(\mathrm{~g})$.

11. The Court permits associations to assert the interests of their members as a basis for standing. See, e.g., UAW v. Brock, 477 U.S. 274 (1986); Hunt v. Washington State Apple Advertising Comm'n, 432 U.S. 333 (1977). See generally RICHARD PIERCE ET AL, ADMINISTRATIVE LAW AND PROCESS $\$ 5.4 .8$ (2d ed. 1992).

12. Lujan v. Defenders of Wildlife, 112 S. Ct. 2130, 2138 (1992).

13. 16 U.S.C. § $1540(\mathrm{~g})(1988)$.

14. Defenders, 112 S. Ct. at 2146 (Kennedy and Souter, JJ., concurring in part and 
Justice Stevens concluded that Defenders of Wildlife had standing to obtain review of the rule but concurred separately in the judgment based on his conclusion that the rule was consistent with the Act. ${ }^{15}$ Two dissenting Justices disagreed with every aspect of the majority opinion's reasoning. ${ }^{16}$

The dissenting Justices accused Justice Scalia of mounting "a slash-and-burn expedition through the law of environmental standing." 17 In one sense, that characterization understates the potential significance of his opinion. Much of the reasoning in the opinion is generally applicable to all standing disputes; the opinion could foreshadow major changes in standing law outside the field of environmental regulation. ${ }^{18}$ In another sense, the dissenting Justices' characterization of the majority opinion is unduly harsh. The opinion includes a great deal of new reasoning about the law of standing. The quality of that reasoning varies widely, however, ranging from a well-reasoned explanation of a relationship the Court had never previously addressed, ${ }^{19}$ to reasoning that is inconsistent with the basic tenets of our legal system. ${ }^{20}$

The majority opinion's conclusion relies on six lines of reasoning: (1) A finding that the plaintiff had tendered inadequate proof of imminent, judicially cognizable injury in fact; ${ }^{21}$ (2) a conclusion that the statutory provision explicitly conferring standing on "any person" was unconstitutional as applied; ${ }^{22}$ (3) a rejection of the plaintiff's alleged injuries based on ecosystem nexus, animal nexus, and professional nexus; ${ }^{23}$ (4) a determination that judicial action would not redress the plaintiff's injuries; ${ }^{24}$ (5) a conclusion that the plaintiff's procedural injury was not sufficient alone to satisfy the requirements for standing, ${ }^{25}$ and (6) a judgment that permitting judicial review at the plaintiff's behest would violate the "take

concurring in the judgment).

15. Id. at 2147.

16. Id. at 2151 (Blackmun and O'Connor, JJ., dissenting).

17. Id. at 2160 .

18. See, e.g., infra text accompanying notes 107-19.

19. See infra text accompanying notes 87-93.

20. See infra text accompanying notes 93-103.

21. Defenders, 112 S. Ct. at 2138.

22. Id. at $2142-46$.

23. Id. at $2139-40$.

24. Id. at $2140-42$.

25. Id. at $2142-43$. 
Care" clause and separation of powers. ${ }^{26}$ Only the first two of these clearly elicited the support of all six Justices who joined in portions of the majority opinion.

\section{A. Inadequate Proof of Judicially Cognizable Injury}

The first of these lines of reasoning (and the first of two which clearly garnered a majority) provides the most narrow potential interpretation of the case; namely, that the plaintiff submitted insufficient evidence to support a finding that one of its members would suffer imminent, judicially cognizable injury in fact. The Court began by enumerating the characteristics of an injury that make it judicially cognizable. The injury must be "concrete and particularized," as well as "actual or imminent, not 'conjectural' or "hypothetical." "27 The opinion concluded that the affidavits failed to meet these standards. The critical deficiency in proof was temporal; the Court held that an expression of an intent to observe a species or its habitat in the future "is simply not enough" to meet the imminent injury standard. ${ }^{28}$ To meet the Court's criteria, one of the affiants presumably was required to testify to her intent to visit the habitat at a specific date in the near future or even to evidence her intent to do so by purchasing a plane ticket. This part of the Court's reasoning is questionable on four grounds.

First, the Court has only required an injury to be "concrete," "particularized," and "imminent" in some cases, and even then, the nature of the injury required to warrant these subjective, conclusory characterizations has varied considerably from case to case. ${ }^{29}$ The Court has recognized many forms of injury that could fairly be characterized as "abstract and general," at least when Congress statutorily recognizes those forms of injury. In Trafficante v. Metropolitan Life Insurance Co. ${ }^{30}$ for instance, the Court held that exclusion of non-whites from an apartment complex sufficiently injured white residents because it deprived them of the social

26. Id. at $2144-46$.

27. Id. at 2136.

28. Id. at 2138.

29. See PIERCE ET AL, supra note 11, § 5.4.4; Richard J. Pierce, Jr., The Role of the Judiciary in Implementing an Agency Theory of Government, 64 N.Y.U. L. REV. 1239, 1276 (1989).

30. 409 U.S. 205 (1972). 
benefits of living in a racially integrated community. Similarly, in Heckler v. Mathews, ${ }^{31}$ the Court held that gender discrimination with no tangible adverse effect constituted injury sufficient to support standing. 32

The Court has also found many injuries that can fairly be characterized as "conjectural," rather than "actual" or "imminent," sufficient to support standing once again when Congress has so ordained. In Association of Data Processing Service Organizations v. Camp ${ }^{33}$ for instance, the Court held that an independent data processing firm had alleged economic injury sufficient to confer on it standing to obtain judicial review of an agency rule authorizing banks to provide data processing services. Yet, ex ante, it was impossible to conclude with any degree of confidence that any particular data processing firm would suffer economic injury. To do so would require the Court to determine which banks, if any, would take advantage of the opportunity to compete with data processing companies, and which data processing companies, if any, would experience diminished net revenues attributable to that competition. The Court saw no need to answer those questions. The companion case of Barlow v. Collins ${ }^{34}$ involved an even more "conjectural" injury. There, the Court allowed a tenant farmer to obtain judicial review of an agency rule permitting the tenant farmer to use the expected proceeds from future crops as loan collateral. The Court found injury attributable to the unproven assertion that the agency, by giving the tenant farmer greater freedom, in fact increased the power of the farmer's landlord to extract unfavorable terms from the tenant. ${ }^{35}$

Second, the Court should not require evidentiary proof of particularized injury as a prerequisite to judicial review of all

31. 465 U.S. 728 (1984).

32. Id. at 737-40; see also Havens Realty Corp. v. Coleman, 455 U.S. 363 (1982) (finding misrepresentation that no apartment was available was sufficient injury even though plaintiff actually did not want an apartment); Abington Sch. Dist. v. Schempp, 374 U.S. 203 (1963) (finding sufficient spiritual injury attributable to leaving class during Bible reading); Engel v. Vitale, 370 U.S. 421 (1962) (finding sufficient spiritual injury attributable to leaving class during prayer).

33. 397 U.S. 150 (1970); see also Clarke v. Securities Indus. Ass'n, 479 U.S. 388 (1987); Investment Co. Inst. v. Camp, 401 U.S. 617 (1970); Arnold Tours-v. Camp, 400 U.S. 45 (1970); American Trucking Ass'ns v. United States, 364 U.S. 1, 17-18 (1960).

34. 397 U.S. 159 (1970).

35. Id. at $163-67$. 
agency actions. The Court has suggested the need for such proof in dicta in only a handful of cases, beginning with its 1978 opinion in Duke Power Co. v. Carolina Environmental Study Group. ${ }^{36}$ In other cases, the Court has resolved the injury question based solely on its evaluation of the pleadings. ${ }^{37}$ Requiring concrete, evidentiary proof of particularized injury makes little sense when a party seeks judicial review of a general rule. Consider, for instance, a petition to review an Environmental Protection Agency rule that would have the uncontroverted effect of increasing emissions of sulfur dioxide in the Midwest. Assume that the petitioner is a resident of the Northeast who regularly travels to several specific lakes in the Adirondacks to trout fish, and he alleges injury in that reduced trout populations diminish his pleasure in trout fishing. The general relationship between sulfur oxide emissions in the Midwest and reduced trout populations in the Adirondacks is, well-documented. ${ }^{38}$ It is impossible, however, to prove or disprove the relationship on a particularized basis, that is, to prove that any particular individual will catch fewer trout in any particular lake as a result of any particular agency action authorizing increased sulfur oxide emissions. Virtually all broadly applicable agency actions present the same problem. A requirement of evidentiary proof of particularized injury in this recurring type of situation is functionally indistinguishable from holding that no one has standing to seek review of an agency action that injures everyone. The Court has repeatedly rejected that proposition. ${ }^{39}$

Generalized allegations of logically plausible forms of individual injury should be sufficient to establish standing to obtain re-

36. 438 U.S. 59 (1978); see also Lujan v. National Wildlife Fed'n, 497 U.S. 871, 885-89 (1990).

37. See, e.g., Barlow, 397 U.S. at 164; Data Processing, 397 U.S. at 153-55.

38. Office of the Director of Research of the National Acid Precipitation Assessment Program, National acid Precipitation Assessment Program ACidic Deposition: STATE OF SCIENCE AND TECHNOLOGY (1990) (a four-volume report of a federal study of acid rain completed at a cost of $\$ 500$ million). These general relationships are classic legislative facts. The Court has consistently held that legislative facts can be resolved without conducting an oral evidentiary hearing. See, e.g., United States v. Florida E. Coast Ry. Co., 410 U.S. 224, 244-46 (1973); see also 2 KENNETH C. DAVIS, ADMINISTRATTVE LAW TREATISE $\& 12.3$ (2d ed. 1979).

39. See, e.g., United States v. SCRAP, 412 U.S. 669, 687-88 (1973); see also Lujan v. Defenders of Wildlife, 112 S. Ct. 2130, 2147 (1992) ("[I]t does not matter how many persons have been injured by the challenged action ....") (Kennedy and Souter, JJ., concurring in part and concurring in the judgment). 
view of agency actions that have broad effects on the public. Judge Frank provided the analytical foundation for this proposition in his famous opinion announcing the "private Attorney Generals" theory of standing. ${ }^{40}$ Because Congress has the power to direct the Attorney General to bring suit to protect the public interest in an agency action, it can authorize such public interest suits by any "person aggrieved" by the agency action instead. ${ }^{41}$

Third, the Court's reliance on a deficiency of detailed proof in the plaintiff's affidavits as the basis for the holding in Defenders seems trivial. At any given point in time, many people have specific plans to visit the habitat of the Nile crocodile and the Asian leopard, and most would be happy to submit an affidavit as a member of Defenders of Wildlife. What purpose is served by requiring the organization to expend significant resources to find the "right" affiant when there is every reason to believe that such people exist and that they share the organization's opposition to the challenged action? It is also hard to take seriously this narrow basis for the decision in Defenders given the extraordinarily broad alternative reasons stated in the opinion. It seems unlikely that the authors of the opinion would withdraw their broad conclusions-for example, their reasoning based on the "take Care" clause-if one of the affiants were to buy a plane ticket to Egypt or Sri Lanka.

Finally, the opinion's inadequate proof of injury basis is premised on an extraordinarily narrow conception of the nature of the injury required to support standing in a case like Defenders. I will suggest broader definitions of injury that are more appropriate to the circumstances, at least when Congress statutorily ordains. ${ }^{42}$

\section{B. The Conclusion That the Statute Was Unconstitutional as Ap- plied}

The only other portion of the majority opinion that clearly garnered the support of six Justices was the conclusion that the statutory provision authorizing "any person" to challenge an agency action that violates the Endangered Species Act was unconstitu-

40. See Associated Indus. v. Ickes, 134 F.2d 694 (2d Cir.), vacated as moot, 320 U.S. 707 (1943).

41. Id. at 704 .

42. See infra text accompanying notes $68-79$. 
tional as applied. The Court had never before held unconstitutional a statutory provision that authorized judicial review of an agency action at the behest of members of a statutorily specified class. Indeed, the Court had consistently respected indications of congressional intent to confer standing on individuals with particular interests in the outcome of agency proceedings. ${ }^{43}$

Cass Sunstein's account of the history of the law of standing demonstrates the extent of the Court's departure from history and tradition in Defenders. ${ }^{44}$ Eighteenth century British and American courts routinely entertained a variety of "citizen suit" actions analogous to the class of judicial proceedings Congress authorized in the Endangered Species Act. ${ }^{45}$ That practice continued in various forms in both U.S. federal and state courts in the period following the drafting of the Constitution. ${ }^{46}$ Standing originated as a prudential doctrine intended to limit the potential for judicial intrusion into areas more appropriately governed by the politically accountable institutions of government. ${ }^{47}$ As such, it obviously had no application to judicial actions specifically authorized by statute. Rather, it simply limited judicial discretion to interfere with actions authorized or taken by politically accountable institutions. ${ }^{48}$ Prior to 1992 , the Court had referred to standing as a potential constitutional constraint in 117 cases, but all 117 of these were decided after 1940; the majority-109-were decided after $1965 .^{49}$ Moreover, until Defenders, the Court had never actually

43. See Block v. Community Nutrition Inst., 467 U.S. 340 (1984); Havens Realty Corp. v. Coleman, 455 U.S. 363 (1982); Duke Power Co. v. Carolina Envtl. Study Group, 438 U.S. 59 (1978); Trafficante v. Metropolitan Life Ins. Co., 409 U.S. 205 (1972); Association of Data Processing Serv. Orgs. v. Camp, 397 U.S. 150 (1970); FCC v. Sanders Bros. Radio Station, 309 U.S. 470 (1940). See generally KeNNETH C. DAVIS \& RICHARD J. PIERCE, ADMINISTRATIVE LAW TREatise $\$ 16.8$ (3d ed. forthcoming 1993); PIERCE ET AL, supra note $11, \& 5.4$.

44. See Cass R. Sunstein, What's Standing After Lujan? Of Citizen Suits, "Injuries," and Article III, 91 MICH. L. REv. 163 (1992). For other good historical accounts, see Raoul Berger, Standing to Sue in Public Actions: Is It a Constitutional Requirement?, 78 YALE L.J. 816 (1969); Henry P. Monaghan, Constitutional Adjudication: The Who and When, 82 YALE L.J. 1363 (1973); Gene R. Nichol, Jr., Injury and the Disintegration of Article III, 74 CAL. L. REv. 1915 (1986); Steven L. Winter, The Metaphor of Standing and the Problem of Self-Govemance, 40 STAN. L. REv. 1371 (1988).

45. See Sunstein, supra note 44 , at $170-74$.

46. See id. at 173-77.

47. See id. at 179-81.

48. See id.

49. See id. at 169. 
used standing as a basis to hold unconstitutional a statute authorizing the judiciary to resolve a class of disputes. ${ }^{50}$ Lower courts were unanimous in holding that statutory provisions explicitly authorizing citizen suits to challenge agency actions were constitutional without the need to find that the plaintiff had suffered a particular type of injury as a result of the agency action at issue. ${ }^{51}$

Until Defenders, the Court deferred to congressional intent with respect to standing where it was able to discern that intent. ${ }^{52}$ If, as Defenders suggests, the Court now believes that standing creates a judicially enforceable limit on congressional discretion, rather than a prudential limit on judicial discretion, both the reasoning and the results of the Court's prior statutory standing cases are in grave doubt. ${ }^{53}$

It is hard to determine the scope and likely effects of the holding of unconstitutionality, however, because the majority opinion and the concurring opinion seem to rely on different reasoning to support that holding. The majority opinion refers to proof of "concrete and particularized" and "actual or imminent" injury as "an essential and unchanging part of the case or controversy requirement of Article III.".54 Interestingly, the oldest of the six cases cited for that proposition was decided in $1972 .{ }^{55}$ In none of those cases did the Court apply that "essential and unchanging" constitutional requirement as the basis for holding a statute unconstitutional. ${ }^{56}$ The Court could not support its assertion in Defenders by citing older cases because its assertion is false. It could not cite any case with a holding that supports its assertion because no

50. See id. at 165.

51. See, e.g., Friends of Earth v. Carey, 535 F.2d 165 (2d Cir. 1976); Natural Resources Defense Council, Inc. v. Train, 510 F.2d 692 (D.C. Cir. 1975); City of Chicago v. General Motors Corp., 467 F.2d 1262 (7th Cir. 1972); Sunstein, supra note 44, at 165 n.10.

52. Block v. Community Nutrition Inst., 467 U.S. 340, 345-48, 352-53 (1984); Havens Realty Corp. v. Coleman, 455 U.S. 363, 372 (1982); Duke Power Co. v. Carolina Envtl. Study Group, 438 U.S. 59, 72-81 (1978); Trafficante v. Metropolitan Life Ins. Co., 409 U.S. 205, 210-12 (1972); Association of Data Processing Serv. Orgs. v. Camp, 397 U.S. 150, 155-56 (1970); FCC v. Sander Bros. Radio Station, 309 U.S. 470, 473-76 (1940).

53. See infra Part II.

54. Lujan v. Defenders of Wildlife, 112 S. Ct. 2130, 2136 (1992).

55. Id. at 2136 (citing Sierra Club v. Morton, 405 U.S. 727 (1972)).

56. See DAVIS \& PIERCE, supra note 43, §§ 16.1, 16.4, 16.5, 16.7, 16.8. 
such case exists. In each of the cited cases, the statement was pure dicta.

The majority opinion then applies the tests announced in dicta in a few recent cases to support its conclusion that Article III precludes Congress from conferring standing on someone who does not meet the demanding tests the Court had previously announced as a limit on judicial discretion. ${ }^{57}$ The majority opinion acknowledges the many prior cases in which the Court had held that "[t]he ... injury required by Art. III may exist solely by virtue of 'statutes creating legal rights, the invasion of which creates standing." "58 It concludes that the citizen suit provision does not fall into this category, however, because statutory "broadening [of] the categories of injury that may be alleged in support of standing is a different matter from abandoning the requirement that the party seeking review must himself have suffered an injury." 59 That statement was dispositive of the constitutional issue, however, only because the majority opinion rejects as "beyond all reason" plaintiff's arguments that it suffered broader forms of injury based on its three nexus theories. ${ }^{60}$

In their separate concurrence, Justices Kennedy and Souter discussed the relationship between a broad statutory grant of standing and the requirement of injury in a way that helps to identify the constitutional flaw they see in the Endangered Species Act's citizen suit provision. They agree with the majority "that there is an outer limit to the power of Congress to confer rights of action," behest of Congress and in the absence of any concrete showing of injury, we were to entertain citizen suits." 62 They explicitly acknowledge Congress's power to confer standing by statute, however, in four ways. First, they express their continuing agreement with the Court's prior holdings that "it does not matter how many persons have been injured by the challenged action." ${ }^{63}$ Second,

57. Defenders, 112 S. Ct. at 2137-46.

58. Id. at 2145 (quoting Warth v. Seldin, 422 U.S. 490,500 (1975) (quoting Linda R.S. v. Richard D., 410 U.S. 614,617 n.3 (1973))).

59. Id. at $2145-46$ (quoting Morton, 405 U.S. at 738).

60. Id. at $2139-40$.

61. Id. at 2147 (Kennedy and Souter, JJ., concurring in part and concurring in the judginent).

62. Id.

63. Id. 
they recognize that regulatory regimes often create judicially enforceable statutory rights that differ from traditional common law rights. ${ }^{64}$ Third, they reaffirm Congress's authority to create rights of action by statute by defining injuries and causal relationships. ${ }^{65}$ Finally, the concurring Justices identify a narrow flaw in the citizen suit provision of the Act that may explain their conclusion that the provision is unconstitutional: "Congress must ... identify the injury ... and relate the injury to the class of persons entitled to bring suit."166

The reasoning of the concurring Justices is hard to reconcile with the Court's general approach to challenges to the constitutionality of federal statutes. Except perhaps when legislation involves suspect categories or fundamental rights, the Court normally does not require the legislature to include in a statute the findings and reasoning necessary to sustain it against constitutional attack. Rather, the Court traditionally has held legislation constitutional if it advances any permissible and plausible legislative purpose, whether or not the legislature stated that purpose in the statute.$^{67}$ Since a broad grant of standing to challenge an agency rule does not raise concerns about fundamental rights or suspect categories, the Court's (and here specifically the two concurring Justices') unwillingness to accord Congress the degree of deference customarily due seems inappropriate.

In any event, unlike the constitutional flaw identified in the majority opinion, the constitutional flaw identified by the concurring Justices is easy to correct. Congress need only identify or create a general public interest in endangered species, and provide explicitly that the deprivation of that interest constitutes an injury that a federal court must vindicate at the behest of any citizen. Cass Sunstein suggests two easy ways Congress could accomplish this. First, it could provide explicitly that all citizens "have a kind of property right-a tenancy in common-in some environmental

64. Id. at 2146 ("[W]e must be sensitive to the articulation of new rights of action that do not have clear analogs in our common-law tradition.").

65. Id. at 2146-47 ("Congress has the power to define injuries and articulate chains of causation that will give rise to a case or controversy where none existed before....").

66. Id. at 2147.

67. See, e.g., Lyng v. Castillo, 477 U.S. 635 (1986); McCulloch v. Maryland, 17 U.S. (4 Wheat.) 316 (1819). See generally LAURENCE H. TRIBE, AMERICAN CONSTITUTIONAL LAW §§ 15-9 to -10 , at $1436-46$ (2d ed. 1988). 
asset,"68 for example, endangered species. Second, Congress could provide a nominal bounty for any citizen who brings a successful action to enforce the Act. ${ }^{69}$ Even the majority opinion in Defenders recognized that a cash bounty would confer on plaintiffs sufficient personal interest to satisfy Article $\mathrm{III} .^{70}$ Alternatively, Congress could adopt by statute one or more of the "nexus" theories of mjury that the plaintiff in Defenders advanced. The majority opinion refused to accept those theories, but the Court would be stretching its power beyond the breaking point if it were to reject as "irrational" a congressional finding that citizens are injured in one of these ways by the loss of endangered species. The concurring Justices explicitly acknowledged that "in different circumstances a nexus theory similar to those proffered here might support a claim to standing."71

\section{Rejection of the Nexus Theories}

The plaintiff urged three "nexus" theories in support of its argument that its affiant-members would suffer imminent injury attributable to projects that would adversely affect endangered species. $^{72}$ "Ecosystem nexus" hypothesizes that a project that impairs a portion of an integrated ecosystem injures anyone who uses any part of that ecosystem. ${ }^{73}$ "Animal nexus" hypothesizes that a project that adversely affects the survival of an endangered species injures anyone who has an interest in observing the species at any location, for example, a zoo. "Vocational nexus" hypothesizes that a project that adversely affects the survival of endangered species injures anyone who has a professional interest in endangered species, for example, as a zookeeper or as a research biologist. ${ }^{75}$ The majority opinion rejects these theories as "beyond all reason." ${ }^{76}$ Three Justices accepted the theories, ${ }^{77}$ however,

68. Sunstein, supra note 44 , at 234.

69. Id. at 232.

70. Defenders, 112 S. Ct. at 2143.

71. Id. at 2146 (Kennedy and Souter, JJ., concurring in part and concurring in the judgment).

72. Id. at $2139-40$.

73. Id. at 2139.

74. Id.

75. Id.

76. Id.

77. Id. at 2148-49 (Stevens, J., concurring); id. at 2154 (Blackmun and O'Connor, JJ., 
and two others indicated that they might be receptive to them "in other circumstances." ${ }^{.78}$ It seems unlikely, then, that a majority of Justices would be willing to characterize as "irrational," and hence unconstitutional, a legislative finding that individuals suffer harm under one or all of the three nexus theories. To do so, the Court would have to characterize as "irrational" congressional adoption of theories of biodiversity that many scientists accept, ${ }^{79}$ as well as the commonsense notion that a biologist who has devoted a lifetime to study of the Asian leopard is injured when the last leopard meets its demise.

\section{Lack of Redressability}

The opinion also concludes that the plaintiff lacked standing because any injury its members might suffer would not be judicially redressable. ${ }^{80}$ That determination is functionally equivalent to a conclusion that the challenged agency action has an insufficient causal relationship to the injury the plaintiff alleged. ${ }^{81}$ Only three Justices joined Scalia in the portion of the opinion on redressability, however.

The opinion concluded that any injury the plaintiff might suffer was not redressable for two reasons. First, because the Department of the Interior was the only agency that was a party to the case, a judicial opinion holding that the Endangered Species Act requires agencies to consult with the Department before funding overseas projects that are likely to have adverse effects on endangered species would bind only the Department and not other agencies. Thus, other federal agencies would be free to ignore the Court's decision if it were to invalidate the Department's rule. That reasoning is inconsistent with precedent. ${ }^{82}$ More fundamentally, it ignores the reality that all federal agencies routinely conform their conduct to decisions of the Su-

dissenting).

78. Id. at 2146 (Kennedy and Souter, JJ., concurring in part and concurring in the judgment).

79. See, e.g., EDWARD O. WILSON, THE DIVERSITY OF LIFE (1992).

80. Defenders, 112 S. Ct. at $2140-42$.

81. See PIERCE ET AL, supra note $11, \S$ 5.4.6.

82. See Sunshine Anthracite Coal Co. v. Adkins, 310 U.S. 381, 402-03 (1940) (stating that a decision against one government agency estops all others because there is privity between officers of the same government); see also United States v. Nixon, 418 U.S. 683, 694-96 (1974) (reasoning that agency rules are binding on the executive branch). 
preme Court. If the Court were to hold that agencies must consult with the Department of the Interior, the agencies would do so. The opinion itself recognizes that the applicable standard is whether a judicial decision is "likely" to redress the plaintiff's injury. ${ }^{83}$ Is the Court seriously suggesting that federal agencies are unlikely to comply with a Supreme Court decision?

Second, the opinion concluded that the injury was not redressable because the U.S. government provides only partial funding for overseas projects. Thus, a foreign government could take the injury-producing actions without American funding. The dissenting Justices devastated that reasoning, pointing out that: The partial funding of one of the projects amounted to $\$ 170$ million in aid to a country with an annual Gross National Product of only $\$ 6$ billion; $; 4$ an agency need not provide $100 \%$ funding of a project in order to be able to influence the manner in which the project is implemented, ${ }^{85}$ and both the Sri Lankan and Egyptian governments had specifically requested the assistance of the U.S. government in devising means of mitigating the potential adverse effects of the projects on endangered species before the Department issued the challenged rule that rendered the Act inapplicable to those projects. ${ }^{86}$

\section{E. Procedural Injury}

The majority opinion also addressed an issue that previously had not received the attention it warrants: In what circumstances can a plaintiff obtain judicial review of an agency action based on an injury to "procedural rights"? The question is important because a high proportion of all administrative law disputes that courts resolve are premised on "procedural" injuries. Typically, a plaintiff alleges denial of adequate notice, an adequate hearing, or an adequate explanation of the basis for an agency action adverse to that party's interests and seeks review based on the (usually implicit) assumption that the agency's provision of the mandatory

83. Defenders, 112 S. Ct. at 2136.

84. Id. at 2157 (Blackmun and O'Connor, JJ., dissenting).

85. Id. at $2156-57$ ("Even if the action agencies supply only a fraction of the funding for a particular foreign project, it remains at least a question for the finder of fact whether threatened withdrawal of that fraction would affect foreign government conduct to avoid harm to listed species.").

86. Id. at 2157. 
procedure would be likely to affect the outcome of the case. ${ }^{87}$ If the majority opinion in Defenders has rejected standing based on such procedural injuries, the field of administrative law will have lost most of its content. Moreover, because most limits on agency discretion are procedural, agencies will enjoy nearly unlimited discretion..$^{88}$

The dissenting Justices severely criticized the majority opinion's treatment of procedural injury as if the Court had eliminated standing based on procedural injury ${ }^{89}$ That criticism is misplaced. The majority opinion concludes that a person cannot obtain judicial review of an agency action based only on injury to a "procedural right." The Court explains and qualifies that conclusion in several important ways:

This is not a case where plaintiffs are seeking to enforce a procedural requirement the disregard of which could impair a separate concrete interest of theirs....90

There is this much truth to the assertion that "procedural rights" are special: The person who has been accorded a procedural right to protect his concrete interests can assert that right without meeting all the normal standards for redressability and immediacy. Thus, ... one ... has standing to challenge ... [an] agency's failure to ... [ [follow a procedure] ... even though he cannot establish with any certainty that [the procedure will change the outcome of the case].9.

....

... We do not hold that an individual cannot enforce procedural rights; he assuredly can, so long as the procedures in

87. See, e.g., Robertson v. Methow Valley Citizens Council, 490 U.S. 332, 345-46 (1989); Motor Vehicle Mfrs. Ass'n v. State Farm Mut. Auto. Ins. Co., 463 U.S. 29, 43, 46 (1983); Mathews v. Eldridge, 424 U.S. 319, 324-25, 343 (1976).

88. See Richard J. Pierce, Jr., The Role of Constitutional and Political Theory in Administrative Law, 64 TEX. L. REv. 469, 473-81 (1985); Peter H. Schuck \& E. Donald Elliot, To the Chevron Station: An Empirical Study of Federal Administrative Law, 1990 DUKE L.J. 984, 1033.

89. Defenders, $112 \mathrm{~S}$. Ct. at $2157-60$ (Blackmun and O'Connor, JJ., dissenting). It is possible that the dissent addressed its criticism only to the majority opinion's discussion of procedural injury. The harsh tone of the dissenting opinion suggests that Justice Scalia may have added the important qualifications regarding procedural rights in footnotes 7 and 8 in response to the dissenting opinion.

90. Id. at 2142 .

91. Id. at 2142 n.7. 
question are designed to protect some threatened concrete interest of his that is the ultimate basis of his standing. ${ }^{92}$

With these qualifications, the majority opinion's treatment of procedural injuries seems well-reasoned, although it raises difficult characterization problems in some contexts. ${ }^{93}$ The fundamental flaws in the majority opinion lie instead in its treatment of substantive injury.

\section{F. Separation of Powers}

Finally, the majority opinion relied on separation of powers and the "take Care" clause of Article II to support its conclusion that Defenders of Wildlife lacked standing. The opinion refers to cases in which the Court declined to permit a plaintiff to challenge government conduct on constitutional grounds where no statute authorized judicial intervention. ${ }^{94}$ It then extended the reasoning of those cases to situations in which Congress has explicitly authorized judicial review of agency action by statute:

To be sure, our generalized-grievance cases have typically involved Government violation of procedures assertedly ordained by the Constitution rather than the Congress. But there is absolutely no basis for making the Article III inquiry turn on the source of the asserted right.

\section{....}

. . . To permit Congress to convert the undifferentiated public interest in executive officers' compliance with the law into an "individual right" vindicable in the courts is to permit Congress to transfer from the President to the courts the Chief Executive's most important constitutional duty, to "take Care that the Laws be faithfully executed." It would enable the courts, with the permission of Congress, "to assume a position of au-

\section{Id. at $2143 \mathrm{n} .8$.}

93. See, e.g., infra lext accompanying notes 107-11.

94. Defenders, 112 S. Ct. at 2143-44 (citing Whitmore v. Arkansas, 495 U.S. 149 (1990); Allen v. Wright, 468 U.S. 737 (1984); Valley Forge Christian College v. Americans United for Separation of Church \& State, 454 U.S. 464 (1982); Schlesinger v. Reservists Comm. to Stop the War, 418 U.S. 208 (1974); United States v. Richardson, 418 U.S. 166 (1974); Doremus v. Board of Educ. of Hawthorne, 342 U.S. 429 (1952); Ex parte LEvitt, 302 U.S. 633 (1937); Frothingham v. Mellon, 262 U.S. 447 (1923); Fairchild v. Hughes, 258 U.S. 126 (1922)). 
thority over the governmental acts of another and co-equal department . . .."."9s

This reasoning is both extraordinary and revealing. In several prior cases, the Court used standing to preclude federal courts from relying on some of the broad language of the Constitution as a source of judicially enforceable constraints on government policies. ${ }^{96}$ Its choice of doctrines was unfortunate, since the Court obviously was not concerned in those cases with the only question standing should answer-who can obtain review of an otherwise reviewable action..$^{97}$ Rather, the effect of the holding in each case was to preclude anyone from obtaining review on the grounds the petitioner asserted. ${ }^{98}$ However, the Court has good reason to limit the scope of potential judicial involvement in government through use of some appropriate doctrine. If the Supreme Court were to authorize federal courts to review each congressional enactment or federal agency action to determine whether, for instance, it is consistent with the vague language of the Tenth Amendment-the issue in Frothingham v. Mellon ${ }^{99}$-it would create a significant risk that in "interpreting" the Tenth Amendment, judges would begin to impose their own versions of federalism. Judicial attempts to give meaning to the malleable language of the Constitution in all contexts could easily evolve into a situation in which politically unaccountable judges displace the politically accountable institutions of government as the source of a high proportion of policy decisions. Thus, in its constitutional standing cases, the Court was exercising judicial restraint in order to further what Alexander Bickel refers to as the "passive virtues."100

In Defenders, however, the Court for the first time transposed this method of avoiding judicial involvement in some classes of disputes into contexts in which Congress has limited agency action by statute and has explicitly called on federal courts to enforce that statutory limit against agencies. ${ }^{101}$ The reasoning in this part

95. Id. at 2144-45 (citing U.S. CONST. art. II, \& 3; Frothingham, 262 U.S. at 489).

96. See, e.g., Allen, 468 U.S. at 737; Warth v. Seldin, 422 U.S. 490 (1975); Frothingham, 262 U.S. at 447.

97. See DAVIS \& PIERCE, supra note $43, \S \S 16.4,16.5,16.7$.

98. Id.

99. 262 U.S. 447 (1923).

100. AlEXANDER M. BiCKEL, THE LEAST DANGerous BRANCH 113-23 (1986).

101. Lujan v. Defenders of Wildife, 112 S. Ct. 2130, 2144-45 (1992). 
of the opinion suggested strongly that the Court's goal is not just to limit the number of people who can bring judicial actions of the type at issue in Defenders, but to avoid all judicial involvement in this class of disputes. It is hard to take seriously the suggestion in the first part of the opinion that the plaintiff would have had standing if only one of its members had purchased a plane ticket to Egypt ${ }^{102}$ when, at the end of the opinion, the Court relied on the "take Care" clause as the basis for its conclusion that Congress cannot transfer power from the President to the courts by enacting a statute that purports to create judicially enforceable limits on the discretion of agencies. ${ }^{103}$

\section{POTENTIAL EFFECTS OF DEFENDERS}

Because of the multiple opinions and multiple lines of reasoning in Defenders, it is impossible to predict with confidence the scope and effect of the holding. In this Part, I will describe four potential effects of Defenders, assuming that a majority of the Court accepts the broad reasoning in the majority opinion and applies that reasoning routinely to resolve all future statutory standing disputes. From my perspective, this is a most pessimistic assumption. I certainly hope the Court interprets the opinion in one of the more narrow ways suggested in Part I. However, a worst-case scenario is illustrative of the opinion's many potential problems.

The holding in Defenders that the citizen suit provision of the Endangered Species Act was unconstitutional as applied has the potential to change the world of administrative law in many important respects. First, scores of environmental statutes have citizen suit provisions. ${ }^{104}$ If the citizen suit provision of the Endangered Species Act is unconstitutional, there is reason to doubt the constitutionality of all other such provisions. ${ }^{105}$ Moreover, if the citizen suit provision in a statute like the Clean Air Act ${ }^{106}$ is un-

102. See id. at 2138.

103. Id. at $2144-45$.

104. See, e.g., Toxic Substances Control Act, 15 U.S.C. \& 2619 (1988); Surface Mining Control and Reclamation Act, 30 U.S.C. \& 1270 (1988), Federal Water Pollution Control Act Amendments of 1972, 33 U.S.C. $\$ 1365$ (1988); Resource Conservation and Recovery Act, 42 U.S.C. $\$ \S 6972,9659,11046$ (1988).

105. See supra text accompanying notes 36-39.

106. 42 U.S.C. \& 7604 (1988). 
constitutional, will anyone other than a regulated firm have standing to seek judicial review of a broadly applicable rule governing emissions levels or ambient air standards? Can anyone other than a regulated firm prove "concrete and particularized" injury? The reasoning in Defenders could produce a situation in which no intended beneficiary of an environmental statute has standing to obtain judicial review of a broadly applicable rule.

Second, the Freedom of Information Act (FOIA) confers on "any person" a judicially enforceable statutory right to obtain nonexempt information in an agency's possession. ${ }^{107}$ The reasoning in Defenders could easily support a holding that FOIA's "any person" standard is unconstitutional. Who can prove "concrete and particularized" injury attributable to an agency's refusal to provide information? Surely not "any person." Is the statutory right to obtain information under FOIA substantive, or is it merely a "procedural right," 108 the denial of which will support standing only if it threatens a "concrete and particularized" substantive injury? Can a reporter or an academic researcher prove "concrete and particularized" injury, or is any injury she suffers too "abstract," "generalized," and "conjectural" to support standing? Perhaps her only interest is derivative of the general public's interest in knowing what the government is doing. If so, that would seem to be an "undifferentiated public interest" that Congress cannot convert "into an 'individual right' vindicable in the courts."109

Will every request to obtain information under FOIA require an evidentiary hearing to determine whether the individual making the request will suffer a "concrete and particularized" injury to an individual substantive right if the agency declines to provide the information? ${ }^{110}$ Who will conduct such hearings? If they are con-

107. 5 U.S.C. $\S 552(\mathrm{a})(3)$ (1988). I am grateful to Peter Strauss for suggesting the relationship between the opinion in Defenders and FOIA.

108. Distinguishing between procedural and substantive rights is notoriously difficult. See, e.g., Hanna v. Plumer, 380 U.S. 460, 472 (1965).

109. Lujan v. Defenders of Wildlife, 112 S. Ct. 2130, 2145 (1992).

110. See supra text accompanying notes $36-39$. Because the inajority opinion in $D e-$ fenders suggests that a plaintiff must prove injury, causation, and redressability in an evidentiary hearing in every case where the government contests the plaintiff's standing, each of the questions posed in this part of the Court's opinion applies to all contested standing cases. In many cases, the inerits are easier to resolve than the standing issue. Consider, for instance, the complicated issues discussed in the inconclusive forty-four page debate of an evenly divided en banc federal appellate court in Center for Auto Safety $v$. Thomas, 847 F.2d 843 (D.C. Cir.), vacated, 856 F.2d 1557 (D.C. Cir. 1988). 
ducted by an agency that desires not to provide the information, how long might it take for the agency to issue a final order resolving the standing dispute based on an evidentiary hearing? In what proportion of cases will an agency that is reluctant to provide information find that the person who requests the information has a right to receive it because she will otherwise suffer a "concrete and particularized" injury to her individual substantive rights? Will reviewing courts accord agency findings of fact relevant to standing the same high degree of deference they routinely accord all other agency findings?

This series of rhetorical questions is meant to suggest that agencies should not be authorized to conduct standing hearings in FOIA cases. Agencies reluctant to disclose information would have a powerful incentive both to stall and to find that the requester does not have standing. The only other alternative consistent with the majority opinion in Defenders raises other serious questions, however. Can the already overburdened district courts conduct evidentiary hearings to resolve FOIA standing disputes in the predictably large number of cases in which agencies challenge an individual's assertion that she will suffer a "concrete and particularized" injury if she does not receive the requested information? How long will such cases take to resolve? What effect will they have on the expected value of information requested under FOIA and on the expected cost of obtaining such information? What effect will such a dramatic change in expectations have on the efficacy of FOIA? It is not difficult to predict the answers to these questions; FOIA could become de facto a statute that merely authorizes agencies to provide requested information when they choose to do so.

Third, the broad reasoning in Defenders would have major effects beyond environmental law and FOIA law. Over the last twenty-five years, the Court's opinions resolving standing disputes have divided into two distinct categories. In cases in which no statute bears on the standing issue, and in which the Court is reluctant to authorize federal judicial intervention, the Court uses

In many contexts, there is no judicial forum available to conduct an evidentiary hearing on standing. The federal appellate courts, which have exclusive responsibility to review most broadly applicable agency actions, are institutionally incapable of conducting evidentiary hearings. See, eg., Investment Co. Inst. v. Board of Governors of Fed. Reserve Sys., 551 F.2d 1270, 1278-80 (D.C. Cir. 1977). 
standing to preclude review. ${ }^{111}$ In this line of cases, the Court describes the nature of the injury required to obtain standing in narrow terms, for example, "particularized and concrete" injury to individual substantive rights. It then applies extraordinarily demanding tests to determine whether the government action at issue caused such a narrowly defined injury and whether a judicial reversal of that action would redress any such narrowly defined injury. These tests are obviously designed to be impossible to satisfy, and in fact have precluded plaintiffs from meeting the jurisdictional predicate for federal judicial intervention in those classes of disputes.

Warth v. Seldin ${ }^{112}$ illustrates this approach to standing. Four different groups of plaintiffs sought judicial review of local zoning rules specifying minimum lot sizes and minimum floor space. The plaintiffs alleged that the zoning rules violated the Fourteenth Amendment because they had the purpose and effect of excluding all poor people and most black people from living in the community. The alleged injuries seemed entirely plausible: Poor people who wanted to live in the community could not afford to do so; builders who wanted to construct low-cost housing suffered economic injury because their construction permit applications were routinely denied on the basis of the zoning rules; neighboring communities suffered harm to their tax base and their social service budget because they were required to absorb a disproportionate share of the region's poor families. The effects of exclusionary zoning are well-documented. ${ }^{113}$ Yet, the Court combined a narrow definition of judicially cognizable injury-that is, "actual or imminent," "concrete and particularized"-and an extraordinarily demanding test of causality and redressability to support its holding that none of the petitioners had standing. ${ }^{114}$

111. See, e.g., Allen v. Wright, 468 U.S. 737 (1984); Simon v. Eastern Ky. Welfare Rights Org., 426 U.S. 26 (1976); Linda R.S. v. Richard D., 410 U.S. 614, 617 (1973).

112. 422 U.S. 490 (1975).

113. See generally Report by the Advisory Commission on Regulatory Barriers to Affordable Housing Before the Subcomm. on Policy Research and Insurance and the Subcomm. on Housing and Community Development, 102d Cong., 1st Sess. (1991) (examining the role of local government land use regulations and their impact on low and moderate income persons); Bernard J. Frieden, The Exclusionary Effect of Growth Controls, 465 ANNALS AM. ACAD. POL. \& SOC. SCI. 123 (1983).

114. Warth, 422 U.S. at 502-08. 
It is not hard to determine what the Court is actually doing in cases like Warth, and why. The Court looks first at the potential consequences of federal judicial intervention in the class of disputes at issue on the grounds asserted by the plaintiffs. In Warth, the Court was asked to make federal district courts available to determine which local zoning and land-use restrictions impose such a disproportionately high burden on poor people that they violate the Equal Protection Clause of the Fourteenth Amendment. The Court's reluctance to authorize federal judicial intervention in this area of government activity on this basis is understandable. Almost every community in the country has a wide variety of zoning and land-use restrictions. Most of those restrictions have adverse effects on the availability of low-cost housing in the community. Some combination of arguably legitimate governmental purposes justifies each such restriction. Authorizing (or, more realistically, requiring) the federal judiciary to determine which of hundreds of thousands of zoning and land-use rules are consistent with some (as yet undevised) test enforcing the Equal Protection Clause would impose extraordinary burdens on local governments and the federal courts. Moreover, any meaningful test would place each federal district judge in a position to exercise significant discretionary judgment with respect to a wide range of policy disputes that politically accountable local institutions traditionally resolve. It is not at all surprising that the Court decided to preclude this result by applying a combination of standing tests that no one can ever satisfy.

The Court has taken a completely different approach to standing in the second category of cases-those involving statutory standing. When a plaintiff relies on a statute as the basis for its standing claim, the Court has consistently resolved the standing issue in accordance with its interpretation of congressional intent. $^{115}$ In this context, the Court routinely has found sufficient injuries that it would have characterized as unduly "abstract" or "generalized" in the context of broad constitutional challenges to classes of government actions where no statute authorizes federal courts to entertain the disputes. In concluding that these forms of

115. Block v. Community Nutrition Inst., 467 U.S. 340, 347 (1984); Havens Realty Corp. v. Coleman, 455 U.S. 363, $372-79$ (1982); Duke Power Co. v. Carolina Envtl. Study Group, 438 U.S. 59, 75-77 (1978); Trafficante v. Metropolitan Life Ins. Co., 409 U.S. 205, 208-11 (1972); Association of Data Processing Serv. Orgs. v. Camp, 397 U.S. 150, 153-58 (1970); FCC v. Sander Bros. Radio Station, 309 U.S. 470, 476-77 (1940). 
injury are sufficient, the Court often refers to the unassailable principle that Congress can create by statute a legal right the violation of which constitutes a judicially cognizable injury. ${ }^{116}$

In the statutory standing context, the Court also routinely has accepted as adequate causal relationships between the challenged agency action and the injury alleged that fall well short of the particularized certainty the Court has demanded when no statute bears on the standing issue. For example, in statutory standing cases, causal relationships that are logically plausible, general, and inherently probabilistic in nature routinely suffice to create standing. ${ }^{117}$ The Court routinely has accepted as adequate plausible allegations that agency action is likely to have an adverse economic effect on individuals or firms in the plaintiff's class. ${ }^{118}$ In a nonstatutory standing case, however, the Court would reject such a causal relationship as "conjectural." In the statutory standing context, the Court has never required plaintiffs to "prove" that the agency action would have an "actual or imminent," "concrete and particularized" adverse economic effect on a specific individual or firm.

In a high proportion of statutory standing cases that the federal courts now routinely review, no prospective plaintiff could meet the extraordinary burden of proof required in the nonstatutory standing context. In Association of Data Processing Service Organizations v. Camp, ${ }^{119}$ for instance, the plaintiff would have had to prove that a specific data processing firm would suffer "concrete and particularized" injury attributable to the potential new competition from one or more banks which the challenged agency action made possible. Conclusory characterizations of the injury as "generalized" or the causal relationship as "conjectural" would thwart any attempt to meet the standard. No one can be certain which, if any, banks will avail themselves of the opportunity to enter the

116. See, e.g., Lujan v. Defenders of Wildlife, 112 s. Ct. 2130, 2145 (1992); Warth, 422 U.S. at 500; see also Trafficante, 409 U.S. at 208-12 (1972) (construing broadly the class of persons able to claim injury under the statute); Hardin v. Kentucky Utils. Co., 390 U.S. 1, 6 (1968) (stating that when a statutory provision reflects a legislative purpose to protect a competitive interest, the injured competitor has standing to require compliance with that provision).

117. See supra cases cited notes $32-33,43$.

118. See, e.g., Data Processing, 397 U.S. at 153-55.

119. 397 U.S. 150 (1970). For a fuller description of the case, see supra text accompanying note 33. 
market and which, if any, specific data processing firms will lose revenues as a result of the competition from such banks. Moreover, the reasoning in Defenders indicates that the plaintiff also would have to "prove" the temporal dimension of the injury-the specific point in time at which it would suffer economic injury attributable to competitive entry in its market.

In short, if the Court, as it suggests in Defenders, applies to statutory standing cases the same impossibly demanding tests it has applied in some of its nonstatutory standing cases, it will create a legal regime in which only regulated firms have standing to obtain judicial review of most broadly applicable agency actions. Regulated firms almost invariably will be able to establish "concrete and particularized" injury directly attributable to agency actions. For anyone else, the injury almost always will be characterized as "generalized" or as the product of an indirect causal chain that is "conjectural" or insufficiently precise and "imminent" in its temporal dimension.

Lastly, if regulated firms are the only entities that can obtain judicial review of most agency actions under the broad reasoning of Defenders, a series of secondary effects is likely to result. First, the law governing rights to intervene and to participate in agency proceedings has tracked changes in the law governing standing to obtain judicial review of agency actions. ${ }^{120}$ If the Supreme Court changes standing law to permit only regulated firms to obtain judicial review of most agency actions, the federal courts of appeals are likely to impose analogous restrictions on rights of intervention and participation in many of the agency proceedings that give rise to those actions. Second, to the extent that individuals, firms, and organizations other than regulated firms retain the right to intervene and participate in agency proceedings, ${ }^{121}$ they will experience a significant reduction in the efficacy of their efforts to persuade the agency. In a world in which agencies can predict with confidence that every decision unfavorable to regulated firms will be subjected to judicial review and that no decision unfavorable to unregulated firms is reviewable, they inevitably will begin to act in

120. See, e.g., Office of Communication of United Church of Christ v. FCC, 359 F.2d 994, 1000-04 (D.C. Cir. 1966). See generally PIERCE ET AL., supra note 11, 5.5 .1 (describing the expansion of eligibility to intervene as an interested party).

121. In rulemaking, the Administrative Procedure Act confers participation rights on all "interested persons." 5 U.S.C. \$ 553(c) (1988). 
accordance with this new incentive structure. Groups and individuals whose interests conflict with those of regulated firms will soon discover that their views are not considered as seriously as the views of regulated firms because only regulated firms can impose on agencies the substantial costs, uncertainties, and delays that attend judicial review. As a result, groups other than regulated firms will decrease the scope and degree of their participation in agency proceedings significantly. This, in turn, will yield ideal conditions for growth in the degree to which regulatees can "capture" their regulatory agencies. ${ }^{122}$ As agencies hear and consider only the views of the firms they regulate, their actions will begin to reflect a myopic view of the world.

The phenomenon of "capture" is a version of the phenomenon the Framers called "factionalism." 123 If the Court applies the broad reasoning in Defenders in all future statutory standing cases, it will have maximized the potential growth of the political pathology the Framers most feared and strived to minimize.

\section{JUSTICE SCALIA'S “AGENDA”}

I suspect Dean Nichol is correct in drawing the inference that Justice Scalia's opinion in Defenders is part of a "broad agenda." 124 However, it is important to recognize the nature of that agenda. Justice Scalia's opinion cannot be considered part of an agenda to reduce the role of the judiciary in government policymaking.

The Court embarked on the agenda of reducing the judicial role in government policymaking in 1972, well before Justice Scalia's time. That agenda has garnered support from every Justice who has served over the last two decades, and many of the critical opinions issued as part of the agenda were unanimous. In 1972 and 1973, the Court held that the statutory term "hearing" did not necessarily mandate formal rulemaking procedures, ${ }^{125}$ thereby according agencies broad discretion to choose decisionmaking proce-

122. See Marver H. Bernsten, Regulating Business by InDEPENDENT CoMmisSION 86-90 (1955); PAUL J. QUIRK, INDUSTRY INFLUENCE IN FEDERAL REGULATORY AGENCIES 8-21 (1981); Richard B. Stewart, The Reformation of American Administrative Law, 88 HARV. L. REV. 1669, 1684-87 (1975).

123. See THE FEDERALIST No. 10 (James Madison).

124. Nichol, supra note 1 , at 1166.

125. United States v. Florida E. Coast Ry. Co., 410 U.S. 224, $240-41$ (1973). 
dures and reducing the discretion of federal courts to set aside agency actions based upon judicial preferences concerning the nature of the "hearing" appropriate to various circumstances. The Court took a larger step in the same direction in Vermont Yankee Nuclear Power Corp. v. Natural Resources Defense Council, Inc. ${ }^{126}$ holding unanimously that courts lack the power to compel agencies to use procedures beyond those statutorily or constitutionally required. ${ }^{127}$ In a series of cases decided between 1974 and 1979, the Court established that only Congress can create a private right of action for violating an agency-administered statute, ${ }^{128}$ thereby eliminating the cacophony and institutional conflicts that had resulted from the Court's prior willingness to allow judges to imply private rights of action in the absence of evidence that Congress intended to create such rights. In 1983, the Court unanimously held that reviewing courts must defer to agency resolutions of policy disputes, ${ }^{129}$ thereby attempting to eliminate the widespread judicial tendency to characterize policy disputes as issues of fact and then to set aside the agency's "findings" because of the scientific uncertainty that surrounds all policy disputes. In 1984, the Court unanimously held that reviewing courts must acquiesce in reasonable agency constructions of ambiguous statutory provisions, ${ }^{130}$ thereby eliminating the widespread practice of judicial resolution of policy disputes in the guise of attributing to Congress an intent to resolve a policy issue Congress did not address. In a series of opinions handed down between 1979 and $1988,{ }^{131}$ the Court reduced the strength and scope of the presumption of reviewability of agency action, thereby precluding courts from undertaking a role in government policymaking in

126. 435 U.S. 519 (1978).

127. Id. at 549 n.21.

128. See National R.R. Passenger Corp. v. National Ass'n of R.R. Passengers, 414 U.S. 453, 457-59 (1974); Cort v. Ash, 422 U.S. 66, 78-79 (1975); Cannon v. University of Chicago, 441 U.S. 677, 688 (1979).

129. Baltimore Gas \& Elec. Co. v. Natural Resources Defense Council, Inc., 462 U.S. 87, 97 (1983).

130. Chevron U.S.A. Inc. v. Natural Resources Defense Council, Inc., 467 U.S. 837, 842-43 (1984).

131. Southern Ry. Co. v. Seaboard Allied Milling Corp., 442 U.S. 444, 454 (1979); Block v. Community Nutrition Inst., 467 U.S. 340, 349-50 (1984); Heckler v. Chaney, 470 U.S. 821, 828-35 (1985); ICC v. Brotherhood of Locomotive Eng'rs, 482 U.S. 270, 278-80 (1987); Webster v. Doe, 486 U.S. 592, 601-02 (1988). 
contexts in which there is reason to believe that Congress intended no judicial role.

I applaud each of these decisions and the broad agenda of which they are a part. A few ill-considered Supreme Court decisions handed down during the period from 1964 to $1971^{132}$ had encouraged many judges to assume a role in government policymaking that was wholly inconsistent with their status as the least politically accountable government officials. Judge Leventhal's famous (or infamous) characterization of the judiciary as the "partner" of the agencies whose actions it reviews ${ }^{133}$ illustrates well the unhealthy extent to which judges felt free to second-guess the politically accountable agencies' policy decisions.

-Indeed, the Court should move to complete this broad agenda. By applying the requirement of "reasoned decisionmaking" the Court legitimated in $1983,{ }^{134}$ reviewing courts continue to intrude inappropriately in government policymaking. Courts frequently rely on this open-ended and infinitely malleable requirement to secondguess agency policies that judges dislike, and to impose demands for encyclopedic analysis of issues and options that no agency can satisfy. ${ }^{135}$ The Court should place further boundaries on this increasingly destructive doctrine in order to deossify the agency policymaking process. ${ }^{136}$

132. See, e.g., J.I. Case Co. v. Borak, 377 U.S. 426, 430-31 (1964) (implying private right of action for violation of agency-administered statute in absence of any evidence that Congress intended to create such a private right of action); Citizens to Preserve Overton Park v. Volpe, 401 U.S. 402, 411 (1971) (announcing strong presumption of reviewability of agency actions and instructing courts to engage in "searching and careful" inquiry into factual support for agency actions).

133. Kennecott Copper Corp. v. EPA, 462 F.2d 846, 848-49 (D.C. Cir. 1972).

134. Motor Vehicle Mfrs. Ass'n v. State Farm Mut. Auto. Ins. Co., 463 U.S. 29, 42-44 (1983).

135. See Jerry L. Mashaw \& David L. Harfs,, The Struggle for auto SaFeTY (1990); Stephen Breyer, Judicial Review of Questions of Law and Policy, 38 ADMIN. L. REv. 363 (1986); Thomas O. McGarity, Some Thoughts on "Deossifying" the Rulemaking Process, 41 DUKE L.J. 1385 (1992); Richard J. Pierce, Jr., The Unintended Effects of Judicial Review of Agency Rules: How Federal Courts Have Contributed to the Electricity Crisis of the 1990s, 43 ADMIN. L. REV. 7 (1991); Richard J. Pierce, Jr., Two Problems in Administrative Law: Political Polarity on the District of Columbia Circuit and Judicial Deterrence of Agency Rulemaking, 1988 DUKE L.J. 300.

136. The Court has reduced the scope of this doctrine to some extent. See Mobil Oil Exploration and Producing S.E. v. United Distribution Cos., 111 S. Ct. 615, 627 (1991); Pension Benefit Guaranty Corp. v. LTV Corp., 496 U.S. 633, $646-49$ (1990). See generally PIERCE ET AL, supra note $11, \S 6.4 .6 \mathrm{~b}$ ("Excessively demanding judicial review has slowed the pace of rulemaking at all agencies ....."). 
The Court's decisions denying standing prior to Defenders also can be characterized as part of its broad agenda to reduce the role of judges in government policymaking. Much of the language of the Constitution is so protean that it fairly can be interpreted to authorize judges to exercise significant discretion with respect to virtually every aspect of government policy. The Tenth Amendment provides a particularly good illustration of the extraordinarily broad role federal judges could take in policymaking if the Court were to authorize federal courts to review all government policies through interpretation and application of all provisions of the Constitution. It is hard to imagine what our legal landscape would look like if each of over eight hundred federal judges had the discretion, and arguably the obligation, to determine which powers are "reserved to the states, respectively, or to the people." ${ }^{\text {"137 }}$ The Court was wise to preclude this result in $1923,{ }^{138}$ even though its choice of standing as the doctrinal vehicle to achieve it was unfortunate.

The majority opinion in Defenders, however, cannot be characterized as part of the Court's agenda to reduce the role of the judiciary in government policymaking. It differs from the Court's prior opinions not in degree, but in kind. All of the Court's prior opinions are consistent with the principle of legislative supremacy. ${ }^{139}$ Thus, for instance, the Court has distinguished clearly among: the judicial obligation to compel agencies to use statutorily mandated procedures, and the lack of judicial discretion to require agencies to use judicially preferred procedures not required by statute $;{ }^{140}$. the judicial obligation to entertain statutorily created private rights of action for alleged violations of agency administered statutes, and the lack of judicial discretion to imply private rights of action that Congress did not create, ${ }^{141}$ the judicial obligation to set aside agencies' statutory interpretations that are inconsistent with congressional resolutions of policy disputes, and the absence of judicial discretion to attribute to Congress resolutions

137. U.S CONST. amend. $X$.

138. See Frothingham v. Mellon, 262 U.S. 447, 483 (1923).

139. For an excellent discussion of the importance of the principle of legislative supremacy, see Daniel A. Farber, Statutory Interpretation and Legislative Supremacy, 78 GEO. L.J. 281 (1989).

140. Vermont Yankee Nuclear Power Corp. v. National Resources Defense Council, Inc., 435 U.S. 519, 546-49 (1978).

141. See Cannon v. University of Chicago, 441 U.S. 677, 688 (1979). 
of policy issues Congress did not address; ${ }^{142}$ and, the judicial obligation to review agency actions Congress intended to subject to judicial review, and the lack of judicial discretion to review agency actions affecting statutory rights when Congress evidenced intent that courts not review those actions. ${ }^{143}$

The Court's prior decisions denying standing also were entirely consistent with the principle of legislative supremacy. In the absence of a statute relevant to the standing issue, the Court often declined to authorize judicial intervention in an area of government policymaking at the behest of an individual who asserted only a "generalized grievance" or whose only injury could be characterized as "abstract" or "conjectural."144 When the Court addressed standing issues in a context in which one or more statutes provided the basis for inferences about congressional intent on standing, the Court resolved the standing dispute in accordance with its interpretation of congressional intent. ${ }^{145}$ Before Defenders, the Court used malleable characterizations of injury, causality, and redressability to further its broad project of reducing judicial involvement in government policymaking, but it used that characterization process in a manner consistent with the principle of legislative supremacy.

The majority opinion in Defenders transposes a doctrine of judicial restraint into a judicially enforced doctrine of congressional restraint. That changes completely the nature of the "broad agenda" that the opinion furthers. The case for judicial restraint is controversial, but is supported by reasoning that is consistent with the form of government we have chosen. ${ }^{146}$ It can be stated in simple terms that everyone understands and that many accept. In a constitutional democracy, politically accountable officers and institutions should have the dominant policymaking roles, subject only to judicially imposed limits that are firmly anchored in the Constitution.

142. See Chevron U.S.A. Inc. v. NationaI Resources Defense Council, Inc., 467 U.S. 837, 842-43 (1984).

143. Webster v. Doe, 486 U.S. 592, 600-01 (1988).

144. See supra cases cited notes $94,111$.

145. See supra cases cited note 43.

146. See generally BICKEL, supra note 100; JOHN H. ELY, DEMOCRACY AND DISTRUST: A THEORY OF JUDICIAL REVIEW (1980). 
The majority opinion in Defenders is simply inconsistent with the principle of judicial restraint. The reasoning in the opinion reallocates power among the institutions of government in three related ways. First, in authorizing, indeed requiring, judges to choose whether to characterize a particular form of injury or causal relationship in a manner that permits the judge to enforce or not to enforce a particular statutory command, it gives courts discretion to decide which congressional policy decisions bind agencies. Judges are more likely to choose characterizations that result in judicial enforcement of a congressional policy decision when they agree with the policy reflected in the statute than when they disagree with that policy. Second, it confers on agencies discretion to ignore many congressional policy decisions. Indeed, extended to its logical limit, the reasoning of the opinion could confer on agencies discretion to ignore all statutory commands or prohibitions that regulated firms prefer they ignore. Third, it takes from Congress the power to make many judicially enforceable policy decisions. Again, carried to its logical limit, the reasoning in Defenders could preclude Congress from making any judicially enforceable policy decisions that have the effect of benefiting only groups rather than identifiable individuals.

The issue on the merits in Defenders makes the case a poor vehicle for illustrating the potential effects of the broad reasoning in the majority opinion. Defenders was not a case in which an agency acted in a manner inconsistent with a clear statutory command. The only Justice who reached the merits concluded that the agency rule was valid because Congress did not intend the Endangered Species Act to have extraterritorial effect. ${ }^{147}$ Suppose, however, that Congress amends the statute to reflect a clear and explicit policy decision that the Act is to have extraterritorial effect; for example, "no federal agency may provide funds for a project in another country if the Department of the Interior determines that the project would violate the substantive provisions of this statute, and every agency must consult with the Department to obtain such a determination before it can provide funds for any project in another country." The broad reasoning of the majority opinion would still yield a holding that federal courts lack jurisdiction to enforce this clear and explicit congressional policy decision

147. Lujan v. Defenders of Wildlife, 112 S. Ct. 2130, 2149-50 (1992) (Kennedy and Souter, JJ., concurring in part and concurring in the judgment). 
because no agency violation of the statute can produce a cognizable form of injury through a cognizable causal sequence.

The majority opinion is not part of a broad agenda of judicial restraint. If it is part of a broad agenda, that agenda is the evisceration of the principle of legislative supremacy. Perhaps a case can be made in support of such an agenda, but I have not seen a convincing argument to that effect. Congress is a politically accountable institution. Courts should enforce its policy decisions against agencies. 